\title{
An Assessment of the Level of Implementation of Procurement Management Practices in the Public Sector
}

\author{
Isidore Komla Zotoo ${ }^{1}$, Rejoice Worlasi Zotoo ${ }^{* 2}$, Lu zhangping ${ }^{3}$ \\ 1, Jiangsu University, School of Management China, \\ ${ }^{2}$ Ghana Communication and Technology University, Ghana
}

\begin{abstract}
This study aimed at assessing the level of implementation of procurement management practices in the public sector of Ghana. To achieve this, the study adopted an exploratory research design and a quantitative research approach. The study further adopted the use of judgement sampling technique and questionnaire were used to select and collect data from 56 employees of the Ghana Revenue Authority.
\end{abstract}

The findings revealed that, the major procurement management practices GRA engages in during a typical procurement process include transparency, information accessibility and availability and efficiency and effectiveness and these practices were visible during the sourcing, contract management, storage, distribution and disposal, qualification and monitoring and evaluation processes. Additionally, it was found that, the level of compliance to the procurement regulations among employees of GRA during a typical procurement process was high.

The findings further revealed that, the execution of procurement management practices at the GRA, face a number of challenges.

The study recommended that, there is a need for more transparency, punishment for flouting of procurement regulations, less government interferences and clarity in communication for employees and suppliers.

Keywords: Procurement practices; Supply Chain management; Ghana; Ghana Revenue Authority

\section{INTRODUCTION}

$\mathrm{E}$ ffective financial management and procurement systems have been one of the developmental challenges facing most developing countries in Sub-Saharan Africa, and Ghana is no exception. According to (Abutabenjeh 2021, Sarfo and Baah-Mintah 2013) financial management, especially public financial management is an attempt made by government to ensure that consistently, the budget is either in balanced or a surplus type. These are largely achieved through ensuring adequate receipts from taxes and non-tax sources and reducing public expenditure levels. Therefore, an improvement in the public procurement process will in no doubt ensure value for money in government expenditure, which is essential to a country facing enormous developmental challenges. According to (Sarfo and Baah-Mintah 2013) procurement as an economic instrument for guaranteeing national development, and when it is well planned and implemented, has the potential of contributing to the realization of the following; improves resource mobilization, promote debt sustainability and effective management of debt, improves public expenditure management, enhances national income generation and reduce economic and financial dependency.

\section{A. Problem statement}

Procurement management practices in the public sector in Ghana are one of the sensitive areas because of the political attachments that are made to it. Successive governments make purchases and award contracts to private organizations through procurement laws but this does not protect it from keen scrutiny from the public. In the process of procuring equipment, materials and undertaking infrastructural projects, it is expected that due process be followed. However, one cannot say with confidence that due process is followed at all times due to the limited transparency observed in the procurement process. In the research carried out by (Edler and Yeow 2016), he observed that public procurement in Europe faces heavy scrutiny because there are multiple stakeholders involved in making sure that the process is without blame. (Bonifield and Cole 2020) in her findings observed that procurement processes in public organizations in Ireland are occasionally plagued with conflict of interest because top management are eventually found to be involved in organizations that win contracts. From the standpoint of (TIREFA 2019) the public procurement processes in Kenya have faced backlash in recent times due to their lack of transparency. This indicates that from a global to an African perspective, procurement practices are laced with high levels of sensitivity.

In the Ghanaian public sector, the ability to separate personal interest from that of the institution is of high interest and this has the tendency of impacting on the sanity of the procurement process(Kwasi 2020). There have been issues related to sole sourcing which the general public and academia share a differing opinion that perhaps a better option could have been used other than sole sourcing. It can be ascertained at this juncture that irrespective of the procurement management practice that is employed in the public sector, there are criticisms attached to it. The Ghana Revenue Authority is observed to be one of the areas that have 
received limited academic traction when it comes to procurement management. Nevertheless, the organization procures materials and equipment and undertakes projects like any other public institution. The limited academic scrutiny in this organization concerning procurement management leaves much to be desired because there are limited empirical findings that point to the effective or otherwise nature of the organization's procurement management practices. This research therefore seeks to fill the academic gap of investigating the existing procurement management practices in the organization. The general objective of this study is to evaluate the level of procurement management practices employed by the Ghana Revenue Authority

\section{B. Empirical Review}

In Akinkunmi, Aghimien, and Awodele (2018) among professionals involved in construction in Nigeria on the factors that affect construction project performance in Nigeria found that project performance was affected by the principles related to the selection of cost time, quality, environmental factors as well as project characteristics (Akinkunmi, Aghimien, and Awodele 2018) Another study in Nigeria on dealing with corruption in Nigeria found that even though procurement laws do exist, its operation is a huge challenge in the public sector ((Nadi 2018). This notwithstanding, Knack, Biletska, and Kacker (2019) observed that sector workers need to be properly managed to make sure that compliance to important regulations, policies and procedures are achieved.

In their study, (Bals and Turkulainen 2017a) found that it was difficult to determine the efficiency and effectiveness of the procurement system because procurement entities in the various departments of public institutions in Uganda are faced with the challenge of not having adequate information on the procurement processes, its inputs, outputs, use of resource and results. In Sönnichsen and Clement (2020) the Challenges confronting Public Procurement Information in Zimbabwe, South Africa, Uganda, and Tanzania are lack of public information about the gains of public procurement, the laws, guidelines, regulations, procedures and governing instruments. There also exists lack of awareness among stakeholders, public procurement markets and complaints review mechanisms. In another study. He stresses that traditionally; firms focus on examining their own internal developments which do not depict the reality of how they relate well with competitors.

A study by Ambe (2019) evaluated the implementation of public sector supply chain management and challenges in Central District Municipality and its local municipalities, North West Province, Republic of South Africa. The study adopted a purposive sampling technique to select 30 respondents within six municipalities through the use of interview guide. The findings of the study revealed that implementation of SCM was far from satisfactory; the municipalities are faced with problems of lack of skills and capacity in the implementation and execution of SCM. Furthermore, non-compliance to SCM regulations was highlighted. The study concludes by recommending that greater sharing of information among those tasked with the implementation of the SCM through the use of technology, establishment of a structure for the implementation of SCM, and in particular structures for public-private partnerships in service delivery, training of municipal employees tasked with the implementation of SCM and stricter application of the public procurement and the Municipal Finance Management Acts. In conclusion, (Suryanto, Haseeb, and Hartani 2018) recommended that, a replication of the study be done in other municipalities to obtain the situation regarding the implementation of supply chain management practices.

\section{Theoretical Review}

The theories adopted by this study included the legitimacy theory (Wilmshurst and Frost 2000) and the Principal Agent theory (Heath and Norman 2004)

1) Legitimacy Theory: This theory affirms that institutions have the command to explain their operations to their respective key actors, especially if it is a public entity should state its benefits to the society (Abdullah et al. 2020) stated that Theory of Legitimacy (LT) is a generalized assumption or perception that the activities of any organization which are workable, appropriate and viable in system which are based on social beliefs, values, definitions and norms. The notion of LT sturdily proposes that the social agreement which is between the government and the public institutions is in position of being eliminated. Based on the context of procurement in public institutions in Ghana, there is likelihood of existence of issues like cronyism, corruption, as well as nepotism which can affect the practice of legitimacy theory. The study therefore employed legitimacy theory to be able to examine whether the procurement officers make disclosure of practice of procurement in order to build a better status with the respective government, key players together with the entire society. Public institutions managers may choose to legitimize and implement procurement practices on the understanding of their states or involved sections. Nevertheless, different public managers seem to differ ideally on the public expectation and their respective local authorities or agencies and even departments as the society views them to comply with their expectations.

2) Principal Agency Theory: This theory is the foundation model employed to ascertain the formation of this study. The economists founded this model to confront the issue related to principal and agents, where agents are persuaded to carry out some task on behalf of the principal (Heath and Norman 2004)The Principal-Agency Theory (PAT) concerns with the understanding that is put in place for an individual or entity (agent) to act in another's interest (principal). The postulations and proposition of PAT fit obviously with the issues concerning procurement and performance. For instance, the government which is in this 
case the principal/shareholder of the Ghana Revenue Authority chooses management (agents) to act on its behalf. For that reason, the procurement management is given power to make decisions on behalf of the government.

In the process of managing supplier quality, buyers in agency relations are likely to be faced by possible risks. By nature, it is the expectation of buyers to get good and improved quality goods and services from suppliers, however, suppliers might be hesitant to spend considerably in quality. (Luu, Cadeaux, and Ngo 2018) observed that the difference between buyers and suppliers always result in the two parties concerning themselves only with their self-interests. PAT establishes the way procurement managers carry out the procurement practices on behalf of public institutions. If there is existence of poor relationship between the principle and agent, then this could affect the relationship between the suppliers and the institutions. This study, therefore, used this model to determine the procurement practices' role and the performance of organizations with focus on Ghana Revenue Authority.

\section{METHODOLOGY}

\section{A. Research design}

According to Harrison et al. (2017) a research design is a step-by-step approach that is used to undertake a research study. Under this study, the design used was exploratory research design. According to Stebbins (2001) an exploratory research is a form of research that is conducted in order to give detailed establishment of problems that have not been studied clearly enough. Exploratory research helps in the designing of operational definitions which are observed in the process of gathering data. This research design was used in the study because when it comes to procurement practices at Ghana Revenue Authority (GRA), not much has been academically done in that area. It is therefore imperative that a research design that can enable deeper understanding of procurement practices be employed for the purposes of offering better understanding.

In the usage of exploratory research under this study, the focus of the research was aimed at making employees of GRA the sole providers of response for the study. This was because the study wanted to determine how employees themselves are able to either adhere to or deviate from regular procurement practices as legally established for the organization.

\section{B. Research approach}

Considering the nature of the objectives and research questions of this study, the study adopted the quantitative research approach. The choice of a quantitative research approach lies with the fact that, the researcher hopes to quantify the opinions of employees in relation to procurement practices and compliance to regulations employed at the Ghana Revenue Authority. According (Bhattacherjee 2012), quantitative research is associated with the measuring of numerical data, texting of hypothesis and generalization of data.

\section{Population}

Population is the list of researchable elements that have the potential of being considered for further sampling under a research activity ((Tufford and Newman 2012)), the population was all employees actively working at Ghana Revenue Authority. To put it in more specific terms, the population of employees at the GRA was 435 employees and this is made up of both contract and permanent workers. The population size was the basis upon which sampling was subsequently made for the research. It can also be understood from this population size that all of the employees may have the propensity of partaking in the study.

\section{Sampling technique}

Under this research, the sampling technique that was adopted was non-probability sampling. Specifically, judgment sampling was used. According to (Tufford and Newman 2012) judgment sampling is a form of sampling in which the research chooses respondents based on her own discretion and the ability of the respondent to provide relevant information to satisfy the research objectives and questions. This sampling technique was adopted for the research because it is not all of the employees (population) that have detailed information and understanding of procurement practices at the GRA. At the same time, the issue of how well or bad procurement activities are carried out need to be observed from an expert point of view. In order to determine this, judgment sampling was selected as the most appropriate sampling technique in order to enable the researcher obtain information that is relevant. Additionally, the usage of judgment sampling provided the researcher the opportunity to streamline responses to meet the desired objectives.

\section{E. Sample size}

This is the actual number of respondents that are considered to participate in data collection activity meant for final analysis by the researcher. It is the preferred quota of respondents that have satisfied the characteristics set forth by the researcher in order to obtain relevant data for analysis. The sample size chosen for this study was 56 respondents. This sample size was stratified into three main categories. These categories were on a departmental basis which included the procurement department, the accounts/finance department and the human resource department. These departments were selected using the judgment method of sampling. The Table 1 shows a breakdown of the sample size

Table 1: Breakdown of Sample Size

\begin{tabular}{|c|c|}
\hline Department & Respondents \\
\hline Procurement & 35 \\
\hline Accounts/Finance & 13 \\
\hline Human Resource & 8 \\
\hline Total & 56 \\
\hline
\end{tabular}




\section{F. Sampling frame}

For the purposes of this research, all respondents that participated in the data collection activity were employees of GRA. Additionally, all of these employees must be permanent employees of the organization without no consideration given to national service personnel, interns and contract workers. Also, the respondents were to have worked for the GRA for a minimum period of two years in order for them to be able to provide the relevant information on procurement practices that are needed by the researcher. Respondents that were able to satisfy all of these criteria but do not belong to any GRA office in Accra was not considered due to proximity reasons. This defined sampling frame therefore set the scene for respondents to be taken from the population.

\section{G. Instrumentation}

The instrument used for data collection was a questionnaire. The questionnaire used for this research was made up of twenty (34) items or questions. These items were sub sectioned in order of the research objectives in order to guide both the respondent and the researcher about the focus of the question.

\section{H. Data collection procedure}

Data was collected from the respondents through personal questionnaire administration. The data collection took a period of two weeks which translates into ten working days. The interview guide was printed in hard copies and initially sent to the respondents for vetting. Although this was not a means to seek approval from the respondents with regards to the structure of questions, the initial vetting by respondents was to serve as a prior notice to them in order for them to prepare.

During the data collection, a recorder was used to tape all of the feedback provided by the respondents. The nature of the interview session was in such a manner that the question was read to the respondent and he/she in turn gives a befitting response verbally. This went on question after question until all of the items in the interview guide have been fully answered by the respondents.

\section{Data analysis}

The data obtained was analyzed quantitatively using SPSS v.20. The analysis was done in resonance to the objectives of the study. Results were presented in Table formats. Some of the analyses conducted included descriptive statistics and correlational analysis.

\section{$J$ Ethical consideration}

The research was carried out by taking into account the conditions of the respondents. None of the respondents were harmed or coerced to provide respondents that suited the researcher in any way. The consent of the respondents was sought before they participated in the study. The respondents were made to understand the purpose of the study and the role they are to play in order to provide answers that are relevant. At the end of engaging the respondents in the interview sessions, they were made to listen to what they have provided. Analysis and commentary were made solely based on the feedback provided by the respondents. The researcher did not at any point in time attempt to alter information in order to skew the analysis in any biased way.

\section{K. Reliability and Validity}

The concept of reliability and validity are used to evaluate the quality of the research being carried and this usually achieved through the use of the questions being asked or used to collect data from participants. They further give an indication of how well the method adopted, technique or test measures the construct understudy as well as measures the consistency and accuracy of the measure.

To test the reliability of the study, A Cronbach Alpha was used and the results shown in the Table 2. From the Table, it is observed that, the Cronbach Alpha was 0.891 which gives an indication of good consistency as well as accuracy of the questionnaire adopted by the researcher.

Table 2 Reliability Statistics

\begin{tabular}{|c|c|}
\hline Cronbach's Alpha & N of Items \\
\hline .891 & 25 \\
\hline
\end{tabular}

\section{RESULT AND DISCUSSION}

\section{A. Procurement Practices}

This section investigates the various types of procurement practices undertaken or engaged in by the employees of the Ghana Revenue Authority. To achieve this, each participant was subjected to a series of questions and asked to respond to them using the Likert Scale ranging from $1-5$ where $1-$ Strongly disagree, $2=$ Disagree, $3=$ Neutral, $4=$ Agree, $5=$ Strongly agree. Their responses are captured on Table 4.

Interaction with the procurement and stores employees of the Ghana Revenue Authority (GRA) revealed that, generally, during a typical procurement process, they ensure transparency during the process. This was evident when it was revealed that, they always ensure " there is enough openness exhibited in the process with which contracting authorities or entities undertake procurement by Single/Sole Sourcing, Restricted Tendering or price Quotation" and also ensuring "documenting and agreeing on any changes or amendments that may arise before or during implementation or execution can be seen as part of the process of systematically and efficiently managing contract creation and execution" are also done during the procurement processes. Furthermore, on the transparency of the procurement process, it was also revealed that, during storage, distribution and disposal processes, they have knowledge of all goods in store, in distribution or auctioning. 
In terms of qualification, it was revealed that, the participants had an open knowledge of all the level of competence of administrators, personnel and contractors and this aids in the improvement of the delivery of service in the departments. Furthermore, with regards to monitoring and evaluation, the study found that, they were fully were aware and also understood all the procedure of monitoring and evaluating in the procurement process is being used in maximizing financial and operational performance and also minimizing risk.

The study further found that, another critical procurement practice engaged in was information accessibility and adequacy. The study found that, the organization also ensured that, in terms of sourcing, there is clarity of information of public sector contract award process across local and central government institutions with the aim of promoting competition from contractors. Additionally, it also found that, with regards to contract management and storage, distribution and disposal, the organization always have adequate knowledge of all the contract negotiations and tendering to ensure compliance during implementation and also ensures that, goods in store, in distribution or auctioning are made a common knowledge to all involved and concerned. Furthermore, with regards to qualification and monitoring and evaluation, the organization and its employees were always familiar with, well informed and have full knowledge of all the rules and regulations guiding procurement processes in the workplace and also were aware and ensured that, monitoring and evaluation was used to generate information on the level of project implementation during contract execution

Finally, on the practices, it was also found that, the organization practices efficiency and effectiveness. It was found that, during procurement processes, political interference, bureaucracy, lack of commitment in following laid down procedures and corruption in offices were very common things that hinders and/or affects contract sourcing process negatively and the participants acknowledge this fact. Furthermore, with regards to contract management and storage, distribution and disposal, the study also found that, quite a number of the participants were in the know that, lack of coordination between procurement departments and approving authorities in different departments do hinder the implementation process, and also value for money is highly considered in storage, distribution or disposal of procured goods

Finally, it was also found that in terms of qualification and monitoring and evaluation, the participants asserted that, their supervisors who make the procurement decisions are knowledgeable in the field and have the ability to deliver and also the effective and efficient monitoring of the implementation of the procurement process and evaluation of the final outcome shows value for money and always does so in the organization
Table 3 Procurement Practices at GRA

\begin{tabular}{|c|c|c|c|c|c|}
\hline Transparency & 1 & 2 & 3 & 4 & 5 \\
\hline $\begin{array}{l}\text { Sourcing: I fully understand } \\
\text { that there is enough openness } \\
\text { exhibited in the process with } \\
\text { which contracting authorities } \\
\text { or entities undertake } \\
\text { procurement by Single/Sole } \\
\text { Sourcing, Restricted } \\
\text { Tendering or price Quotation }\end{array}$ & $8.9 \%$ & $1.8 \%$ & $46.4 \%$ & $30.4 \%$ & $12.5 \%$ \\
\hline $\begin{array}{l}\text { Contracting: I can confirm } \\
\text { that documenting and } \\
\text { agreeing on any changes or } \\
\text { amendments that may arise } \\
\text { before or during } \\
\text { implementation or execution } \\
\text { can be seen as part of the } \\
\text { process of systematically and } \\
\text { efficiently managing contract } \\
\text { creation and execution }\end{array}$ & $3.6 \%$ & $1.8 \%$ & $35.7 \%$ & $46.4 \%$ & $12.5 \%$ \\
\hline $\begin{array}{l}\text { Storage, distribution } \boldsymbol{\&} \\
\text { disposal: Goods in store, in } \\
\text { distribution or auctioning are } \\
\text { a common knowledge to all } \\
\text { of us involved and concerned }\end{array}$ & $5.4 \%$ & $1.8 \%$ & $41.1 \%$ & $37.5 \%$ & $14.3 \%$ \\
\hline $\begin{array}{l}\text { Qualification: Open } \\
\text { knowledge of the level of } \\
\text { competence } \\
\text { administrators, personnel and } \\
\text { contractors has improved the } \\
\text { level of service delivery in } \\
\text { our department }\end{array}$ & $3.6 \%$ & $21.4 \%$ & $26.8 \%$ & $42.9 \%$ & $5.4 \%$ \\
\hline $\begin{array}{l}\text { Monitoring \& Evaluation: } \\
\text { In my work, a well-known } \\
\text { and/or a well understood } \\
\text { procedure of monitoring and } \\
\text { evaluating in the procurement } \\
\text { process is being used in } \\
\text { maximizing financial and } \\
\text { operational performance and } \\
\text { also minimizing risk. }\end{array}$ & $5.4 \%$ & $3.6 \%$ & $25.0 \%$ & $55.4 \%$ & $107 \%$ \\
\hline Information & 1 & 2 & 3 & 4 & 5 \\
\hline $\begin{array}{l}\text { Sourcing: There is clarity of } \\
\text { information of public sector } \\
\text { contract award process across } \\
\text { local and central government } \\
\text { institutions promotes } \\
\text { competition from contractors }\end{array}$ & $1.8 \%$ & $14.3 \%$ & $48.2 \%$ & $26.8 \%$ & $9.0 \%$ \\
\hline $\begin{array}{l}\text { Contract management: } \\
\text { There is adequate knowledge } \\
\text { of all the contract } \\
\text { negotiations and tendering to } \\
\text { ensure compliance during } \\
\text { implementation }\end{array}$ & $3.6 \%$ & $1.8 \%$ & $28.6 \%$ & $48.2 \%$ & $17.9 \%$ \\
\hline $\begin{array}{l}\text { Storage, distribution } \boldsymbol{\&} \\
\text { disposal: I understand that } \\
\text { goods in store, in distribution } \\
\text { or auctioning are a common } \\
\text { knowledge to all involved } \\
\text { and concerned }\end{array}$ & $1.8 \%$ & $3.6 \%$ & $48.2 \%$ & $32.1 \%$ & $14.3 \%$ \\
\hline $\begin{array}{l}\text { Qualification: I am familiar } \\
\text { with, well informed and have } \\
\text { full knowledge of all the } \\
\text { rules and regulations guiding } \\
\text { procurement processes in my } \\
\text { workplace. }\end{array}$ & $1.8 \%$ & $3.6 \%$ & $28.6 \%$ & $46.4 \%$ & $19.4 \%$ \\
\hline $\begin{array}{l}\text { Monitoring \& Evaluation: I } \\
\text { am aware that monitoring and }\end{array}$ & $1.8 \%$ & $3.6 \%$ & $33.9 \%$ & $41.1 \%$ & $19.4 \%$ \\
\hline
\end{tabular}




\begin{tabular}{|c|c|c|c|c|c|}
\hline $\begin{array}{l}\text { evaluation is used to generate } \\
\text { information on the level of } \\
\text { project implementation } \\
\text { during contract execution }\end{array}$ & & & & & \\
\hline Efficiency and effectiveness & 1 & 2 & 3 & 4 & 5 \\
\hline $\begin{array}{l}\text { Sourcing: Political } \\
\text { interference, bureaucracy, } \\
\text { lack of commitment in } \\
\text { following laid down } \\
\text { procedures and corruption in } \\
\text { offices do hinders and/or } \\
\text { affects contract sourcing } \\
\text { process negatively }\end{array}$ & $5.4 \%$ & $0.0 \%$ & $17.9 \%$ & $44.6 \%$ & $32.1 \%$ \\
\hline $\begin{array}{l}\text { Contract management: I } \\
\text { understand that lack of } \\
\text { coordination } \quad \text { between } \\
\text { procurement departments and } \\
\text { approving authorities in } \\
\text { different departments do } \\
\text { hinder the implementation } \\
\text { process }\end{array}$ & $7.1 \%$ & $0.0 \%$ & $16.1 \%$ & $42.9 \%$ & $33.9 \%$ \\
\hline $\begin{array}{l}\text { Storage, distribution \& } \\
\text { disposal: Value for money is } \\
\text { considered in storage, } \\
\text { distribution or disposal of } \\
\text { procured goods }\end{array}$ & $5.4 \%$ & $0.0 \%$ & $16.1 \%$ & $42.9 \%$ & $35.7 \%$ \\
\hline $\begin{array}{l}\text { Qualification: My superiors } \\
\text { who make the procurement } \\
\text { decisions are knowledgeable } \\
\text { in the field and have the } \\
\text { ability to deliver }\end{array}$ & $5.4 \%$ & $0.0 \%$ & $14.3 \%$ & $44.6 \%$ & $35.7 \%$ \\
\hline $\begin{array}{l}\text { Monitoring \& Evaluation: } \\
\text { The effective and efficient } \\
\text { monitoring of the } \\
\text { implementation of the } \\
\text { procurement process and } \\
\text { evaluation of the final } \\
\text { outcome shows value for } \\
\text { money and always does so in } \\
\text { my organization }\end{array}$ & $5.4 \%$ & $0.0 \%$ & $14.3 \%$ & $44.6 \%$ & $35.7 \%$ \\
\hline
\end{tabular}

\section{B. $\quad$ Compliance to Procurement Regulations}

This section investigates the level of compliance to procurement regulations engaged in by the employees of the Ghana Revenue Authority. Again, to achieve this, each participant was subjected to a series of questions and asked to respond to them using the Likert Scale ranging from $1-5$ where 1 - Strongly disagree, $2=$ Disagree, $3=$ Neutral, $4=$ Agree, $5=$ Strongly agree. Their responses are captured on Table 4.

Interaction with the participants through the questionnaire revealed that, there was generally a high level of compliance to the procurement regulations during the procurement process. According to them, they were aware and adheres to the written legal binding agreement between contracting parties identifies rights and obligations of both parties involved in the procurement process and this was confirmed by over $90 \%$ of the participants. Furthermore, in terms of storage, distribution and disposal, the findings revealed that, the over $80 \%$ of the participants "agreed" and "strongly agree" to the claim that, "Need to store unused goods, the timely availability of goods and the disposal of unserviceable, obsolete or surplus stocks are always done within the remits of public tendering and other laws guiding procurement".

Finally, in terms of qualification and monitoring and evaluation, the findings revealed that, over $70 \%$ "agreed" and "strongly agreed" to the claims that, "I am fully aware that the use of unqualified personnel in the procurement process whether as official or suppliers breeds corruption and it breaks the laws guiding the process" and "I do know that all processes of procurement from sourcing through tendering to execution are monitored and evaluated within the framework of the laws governing procurement" respectively.

Nevertheless, when posed with the claim that, "I am fully aware that pre-qualification of potential suppliers, preparation and issue of tender documents, requests for quotations or for proposals; evaluation of responses and the selection of the successful tenderer are done in accordance with procurement laws" only quite a number of them representing $44.6 \%$ responded agree while $1.8 \%$ responded "strongly agree". However, $33.9 \%$ remain neutral to give the implication that, they were not fully aware or were not much previewed to whether or not these pre-qualifications of potential suppliers, preparation and issue of tender documents, requests for quotations or for proposals; evaluation of responses and the selection of the successful tendering processes are done in accordance to the procurement law.

Table 4 Compliance to Procurement Processes at GRA

\begin{tabular}{|c|c|c|c|c|c|}
\hline & 1 & 2 & 3 & 4 & 5 \\
\hline $\begin{array}{l}\text { Sourcing: I am fully aware } \\
\text { that pre-qualification of } \\
\text { potential suppliers, } \\
\text { preparation and issue of } \\
\text { tender documents, requests } \\
\text { for quotations or for } \\
\text { proposals; evaluation of } \\
\text { responses and the selection } \\
\text { of the successful tenderer } \\
\text { are done in accordance with } \\
\text { procurement laws }\end{array}$ & $5.4 \%$ & $14.3 \%$ & $33.9 \%$ & $44.6 \%$ & $1.8 \%$ \\
\hline $\begin{array}{l}\text { Contract management: I } \\
\text { do know that a written } \\
\text { legally binding agreement } \\
\text { between contracting parties } \\
\text { identifies rights and } \\
\text { obligations of both parties } \\
\text { involved in the } \\
\text { procurement process }\end{array}$ & $5.4 \%$ & $0.0 \%$ & $3.6 \%$ & $87.5 \%$ & $3.6 \%$ \\
\hline $\begin{array}{l}\text { Storage, distribution \& } \\
\text { disposal: Need to store } \\
\text { unused goods, the timely } \\
\text { availability of goods and } \\
\text { the disposal of } \\
\text { unserviceable, obsolete or } \\
\text { surplus stocks are always } \\
\text { done within the remits of } \\
\text { public tendering and other } \\
\text { laws guiding procurement. }\end{array}$ & $5.4 \%$ & $0.0 \%$ & $14.3 \%$ & $44.6 \%$ & $35.7 \%$ \\
\hline $\begin{array}{l}\text { Qualification: I am fully } \\
\text { aware that the use of } \\
\text { unqualified personnel in the } \\
\text { procurement process }\end{array}$ & $5.4 \%$ & $0.0 \%$ & $1.8 \%$ & $19.6 \%$ & $73.2 \%$ \\
\hline
\end{tabular}




\begin{tabular}{|c|c|c|c|c|c|}
\hline $\begin{array}{l}\text { whether as official or } \\
\text { suppliers' breeds corruption } \\
\text { and it breaks the laws } \\
\text { guiding the process }\end{array}$ & & & & & \\
\hline $\begin{array}{l}\text { Monitoring \& Evaluation: } \\
\text { I do know that all processes } \\
\text { of procurement from } \\
\text { sourcing through tendering } \\
\text { to execution are monitored } \\
\text { and evaluated within the } \\
\text { framework of the laws } \\
\text { governing procurement }\end{array}$ & $5.4 \%$ & $0.0 \%$ & $17.9 \%$ & $7.1 \%$ & $69.6 \%$ \\
\hline
\end{tabular}

\section{Stakeholders Participation in Procurement} Processes

This section investigates the various stakeholders' participation in procurement processes from the perspective of the employees at GRA. To achieve this, each participant was subjected to a series of questions and asked to respond to them using the Likert Scale ranging from $1-5$ where 1 Strongly disagree, 2 = Disagree, $3=$ Neutral, $4=$ Agree, $5=$ Strongly agree. Their responses are captured on Table 5.

From the Table, it can be concluded that, generally procurement and stores employees of the Ghana Revenue Authority (GRA) ensures that, during a typical procurement process, all the various stakeholders are involved. This was evident when the majority representing over $70 \%$ of them responded "agree" and "strongly agree" respectively to the claims that, "From planning to sourcing, my unit engages all stakeholders from various departments, relevant agencies and contractors" in terms of sourcing. Furthermore, it was also revealed that, with regards to contracting, the organization ensures that, "Top management, contractors and all departments are involved in the tender and contract negotiation process" and this was also confirmed by over $70 \%$ of the participants. Additionally, investigating the participation of stakeholders during the storage, distribution and disposal, qualification and monitoring and evaluation, it was also revealed that, the organization during a typical procurement process ensures that, "Distribution and disposal of purchases end up at the right place with the right people", "Participants involved in executing and reviewing procurement of contracts have experience and knowledge in the field" and "there is constant communication among stakeholders at all levels of the implementation of the procurement processes". these assertions or claims were supported with agree and strongly agreement responses of over $70 \%$ by the participants.

Table 5 Stakeholders' Participation in Procurement Processes at GRA

\begin{tabular}{|c|c|c|c|c|c|}
\hline & 1 & 2 & 3 & 4 & 5 \\
\hline $\begin{array}{l}\text { Sourcing: From planning to } \\
\text { sourcing, my unit engages all } \\
\text { stakeholders from various } \\
\text { departments, relevant } \\
\text { agencies and contractors }\end{array}$ & $5.4 \%$ & $0.0 \%$ & $16.1 \%$ & $44.6 \%$ & $33.9 \%$ \\
\hline $\begin{array}{l}\text { Contracting: } \\
\text { management, contractors and } \\
\text { all departments are involved }\end{array}$ & $5.4 \%$ & $0.0 \%$ & $16.1 \%$ & $76.8 \%$ & $1.8 \%$ \\
\hline
\end{tabular}

\begin{tabular}{|l|l|l|l|l|l|}
\hline $\begin{array}{l}\text { in the tender and contract } \\
\text { negotiation process }\end{array}$ & & & & & \\
\hline $\begin{array}{l}\text { Storage, Distribution and } \\
\text { Disposal: Distribution and } \\
\text { disposal of purchases end up } \\
\text { at right place with the } \\
\text { right people }\end{array}$ & $5.4 \%$ & $0.0 \%$ & $16.1 \%$ & $39.3 \%$ & $39.3 \%$ \\
\hline $\begin{array}{l}\text { Qualification: Participants } \\
\text { involved in executing and } \\
\text { reviewing procurement of } \\
\text { contracts have experience } \\
\text { and knowledge in the field }\end{array}$ & $5.4 \%$ & $0.0 \%$ & $14.3 \%$ & $41.1 \%$ & $39.3 \%$ \\
\hline $\begin{array}{l}\text { Monitoring and Evaluation: } \\
\text { I understand that there is } \\
\text { constant communication } \\
\text { among stakeholders at all } \\
\text { levels of the implementation } \\
\text { of the procurement processes }\end{array}$ & $5.4 \%$ & $0.0 \%$ & $3.6 \%$ & $51.8 \%$ & $39.3 \%$ \\
\hline
\end{tabular}

The study further investigated by seeking the views of the participants, the various stakeholders involved in a typical procurement process. Their responses are captured on Table 8 below. From the Table, it is observed that, the board of directors and workers in procurement department were the most prominent stakeholders in a typical procurement process. This was confirmed by $91.3 \%$ respectively by the participants. Furthermore, it was revealed that, top management and workers in the stores department were also stakeholders in a typical procurement process. This was also confirmed by $87 \%$. However, only $4.3 \%$ of the participants were of the belief that, workers in the stores department could considered as stakeholders in a typical procurement process.

Table 6 Stakeholders in Procurement Process.

\begin{tabular}{|c|c|c|c|}
\hline \multicolumn{2}{|c|}{} & $\begin{array}{c}\text { Coun } \\
\mathrm{t}\end{array}$ & Percent \\
\hline \multirow{3}{*}{$\begin{array}{c}\text { Various Stakeholders } \\
\text { in a Procurement } \\
\text { Process }\end{array}$} & Board of directors & 21 & $91.3 \%$ \\
\cline { 2 - 4 } & $\begin{array}{c}\text { Top management } \\
\text { Wrocurement } \\
\text { department }\end{array}$ & 21 & $87.0 \%$ \\
\cline { 2 - 4 } & $\begin{array}{c}\text { Workers in the stores } \\
\text { department }\end{array}$ & 1 & $4.3 \%$ \\
\hline
\end{tabular}

\section{Challenges Encountered in Procurement Processes}

This section investigated the various challenges employees of GRA face during a typical procurement process. To achieve this, each participant was asked to state some of the challenges they faced.

From their responses, it can be suggested that, the most common challenge faced during a typical procurement process were the presence of risk mitigation, long process cycle and inaccurate data. This was confirmed by $39.3 \%$ of the participants. Furthermore, it was also revealed that, bureaucratic processes as a result of paper as well as government interference during the procurement process were also challenges employees of GRA faced when executing or undergoing a typical process. These were also confirmed by $26.8 \%$ and $8.9 \%$ respectively as shown on Table 7 below. 
Table 7 Challenges Encountered in Procurement Processes

\begin{tabular}{|c|c|c|c|}
\hline & Frequency & Percent \\
\hline $\begin{array}{c}\text { Bureaucratic processes due to } \\
\text { paperwork }\end{array}$ & 15 & 26.8 \\
\hline $\begin{array}{c}\text { Government interference } \\
\text { Risk Mitigation, Long } \\
\text { Process Cycle, Inaccurate } \\
\text { Data }\end{array}$ & 5 & 8.9 \\
\hline No response & 14 & 39.3 \\
\hline
\end{tabular}

Nevertheless, the study further sought the opinion of the participants on how these challenges faced or encountered during a typical procurement process are tackled or curb. From their responses, it was revealed that, having the right tools enables them to face head on the challenges they encounter during the procurement process. Additionally, some were of the opinion that, the interference of government in procurement processes was inevitable, however, should the government allow organizations such as the GRA to take their own decisions with regards procurement processes, it will go a long way to help curb some of these challenges. Finally, it was revealed that, due to the bureaucratic processes as well as long process cycle, there is a current introduction of an electronic procurement system which allows employees to now perform all procurement processes electronically thereby reducing the paper work as well as reducing the human interventions and errors.

\section{E. Relationship between Procurement Practices and Compliance to Procurement Regulations}

This section investigated the relationship between procurement practices and the compliance to the procurement regulations by the procurement and stores employees of the Ghana Revenue Authority. To achieve this, a correlation analysis conducted at the 0.05 level of significance was used. The choice a correlation analysis lies with the face that, it allows the researcher to establish any form or relationship between two variables and in this case between procurement practices and compliance to procurement regulations. The results are shown on Table 8 .

From the Table 8 , it is observed that Pearson Correlation value between Procurement Practices and Compliance to Procurement Regulations was 0.540. These values give the implication that, there is strong positive relationship between procurement practices and compliance to the procurement regulations. It further gives the indication that, the more engagement in the procurement practices, the more adherence to the procurement regulations. Furthermore, the Table showed that, the p-value was 0.000 which also gives the indication that, aside the relationship being a strong and positive, it is also a very significant relationship.
Table 8: Correlation between Procurement Practices and Compliance to Procurement Regulations

\begin{tabular}{|c|c|c|}
\hline \multirow{2}{|c|}{} & $\begin{array}{c}\text { Procurement } \\
\text { Practices }\end{array}$ \\
\hline \multirow{2}{*}{$\begin{array}{c}\text { Compliance to } \\
\text { Procurement } \\
\text { Regulations }\end{array}$} & Pearson Correlation & .540 \\
\cline { 2 - 3 } & Sig. (2-tailed) (p-value) & .000 \\
\cline { 2 - 3 } & $\mathrm{N}$ & 53 \\
\hline
\end{tabular}

Source: Field work, 2020

\section{F. Discussion}

The findings revealed that, the challenges encountered during procurement processes at the Ghana Revenue Authority included bureaucratic processes due to paper work, government interference risk mitigation, long process cycle and inaccurate data. This gives the implication that, the government of Ghana does have some level of interference in the procurement processes of public institutions like GRA and this does have negative impact on the performance of the organization and effectively processing of procurement issues of the organization. Furthermore, it gives the implication that, the presence of inaccurate data during a procurement process will hinder the availability and accessibility of accurate data. Furthermore, it gives the implication that, the presence of inaccurate data will eventually hinder the efficiency and effectiveness of the whole procurement process.

The above findings conform to the study by (Bals and Turkulainen 2017b)who found that it was difficult to determine the efficiency and effectiveness of the procurement system because procurement entities in the various departments of public institutions in Uganda are faced with the challenge of not having adequate information on the procurement processes, its inputs, outputs, use of resource and results.

Furthermore, the study found that, the procurement practices deployed during procurement process in Ghana Revenue Authority include transparency, information availability and accuracy and efficiency and effectiveness. This gives the implication that, the procurement processes at GRA to a large extent ensures clarity with adequate information of public sector award process and this assertion conforms with the study by (Lyrio, Lunkes, and Taliani 2018) who stated that, Transparency aims at ensuring clarity with adequate information of public sector award process across local and central government institutions which promote competition from contractors. Even though most legal instruments guiding public procurement prescribe that this principle is observed, it is left in the hands of public administrators responsible for the procurement role to apply it due to their discretionary powers. Hence, observing this principle has been difficult globally over the past decade.

Further findings also revealed that, the level of compliance to the procurement regulations was very high at the Ghana Revenue Authority. This gives the implication that, this saves the organization from issues of loss of funds and other corrupt issues that may crop up as a result of lack of 
compliance of the procurement regulations. This finding conforms to the study by (Titl and Geys 2019) who found that, enormous funds are lost every year because public procurement policies are poorly managed. In view of this, public sector workers need to be properly managed to make sure that compliance to important regulations, policies and procedures are achieved.

Finally, the study found the stakeholders involved in the procurement process included board of directors, top management, workers in procurement department and workers in the stores department and their various roles in the implementation of the procurement processes included

\section{CONCLUSION}

It can be concluded from the findings that procurement practices at GRA is at acceptable means in terms of how they are managed by officials within the organization. Results from the findings led to the conclusion that there are multiple parties involved in deciding which supplier can provide the best material for any department that needs it. The centralized nature of procurement at GRA as found in many other public organizations in Ghana also requires that departments in the organization must be deeply involved in what is being procured on their behalf. It was also concluded that although the procurement unit of the GRA has expert knowledge when it comes to how and where they can get materials at cost competitive process, the various departments that will be using the materials or stock are also in the best position to provide expert knowledge. This makes them valuable stakeholders and representatives when it comes to the procurement management process.

It can also be concluded that, generally there was a high level of compliance to the procurement regulations during the procurement process.

Furthermore, it can be concluded that, the level of participation from the perspective of the stakeholders involved in procurement processes at the Ghana Revenue Authority was very high as every stakeholder was involved in the processes.

Finally, it can be concluded that, some of the challenges encountered during procurement process at the Ghana Revenue Authority included Bureaucratic processes due to paperwork, Government interference and Risk Mitigation, Long Process Cycle, Inaccurate Data.

\section{A. Recommendations}

1) Transparency in procurement practices: Transparency can be difficult to achieve when there is minimal communication in the management process. When contracts and agreements are shrouded in secrecy, it becomes challenging for them to be independently evaluated to determine whether the right steps were followed or not. In the findings analyzed, it was observed that most of the respondents are of the view that procurement practices at GRA are transparent in nature and there is also constant monitoring of the process. It is also a matter of interest that having an opinion about a process being transparent because the individual is a part of the process is not the same as the process itself being transparent. It is suggested for consideration that there should be efforts made at designing procurement process in such manner that every stage is documented. The documentation should not be shelved after they have been made but must be made public to the relevant audience. The reason for this is to ensure that value for money was achieved in the process. There must be an overriding assessor who is accountable to the general public and the courts of law should any procurement decision go wrong. This is the general rhetoric, but nothing is being done to enforce it because the secretive nature of most procurement practices does not give the general public an opportunity to figure out who did what wrong.

2) Punishment for flouting procurement laws: The government must work with security agencies and active whistleblowers to ensure that severe punishment is meted out to those who mismanage public funds under the guise of procurement. In times past, sole sourcing has been observed to be rampant and later investigations have also revealed that the very stock or service that was solely sourced could have been purchased at better rates and the state could have been saved heavy funds. All these occur because there is no apparent punishment for those that go contrary to procurement practices as enshrined in law.

3) Consideration for recommendations from Public Accounts Committee (PAC): It is also important that the same legal instrument that gives the PCA authority to summon officers from public organizations should also make it mandatory for their recommendations to be put to practice. Lest the commission only becomes a television or radio show for public officials to appear on. In moving forward as a nation and also from the perspective of Ghana Revenue Authority, attempts must be made to ensure that recommendations suggested from multiple credible sources which include the PAC are taken into account. It is only by doing so that defects in the procurement process can be adequately dealt with.

2) Clarity in communication for employees and suppliers: There is the need to have clarity in communication. The rules and regulations that are to be followed by employees to ensure that procurement is correctly done must be simplified but the value must not be taken away either. All employees that are directly or indirectly connected with procurement process must be trained on what to look out for, what information to pass on to the outside (inquirers and potential suppliers). This is because it is not all the time that procurement process begins in a formal manner. There should therefore be clarity in the type of information that is provided and they must be made handy as well.

\section{B. Areas of further research}

In the current study that was carried out, the general observation made was that Ghana Revenue Authority (GRA) 
and it is recommended that for future academic research, emphasis should be laid on investigating the role of the Public Accounts Committee (PAC) in helping to minimize instances of procurement opacity and challenges. This is because as the commission deals with public organizations, their recommendations and actions can be instrumental in reducing bottlenecks that are found in public institutions in the area of procurement.

\section{ACKNOWLEDGEMENTS}

This work was supported by the Chinese National Social Science Foundation (No. 16BTQ004, 17BTQ025) and the Philosophy and Social Science Fund of Education Department of Jiangsu Province (No. 2019SJA1871)

\section{REFERENCES}

[1] Abdullah, Maizatulakma, Noradiva Hamzah, Mohd Helmi Ali, Ming-Lang Tseng, and Matthew Brander. 2020. "The Southeast Asian haze: The quality of environmental disclosures and firm performance." Journal of Cleaner Production 246:118958.

[2] Abutabenjeh, Sawsan. 2021. "Strategic management in state government two servants of the same master: Procurement and finance." International Journal of Public Administration 44 (7):607-621.

[3] Akinkunmi, Olutayo Gabriel, Douglas Omoregie Aghimien, and Oluwaseyi Alabi Awodele. 2018. "Appraising the use of labouronly procurement system for building construction in Nigeria." Organization, technology management in construction: an international journal 10 (1):1719-1726.

[4] Ambe, Intaher Marcus. 2019. "The role of public procurement to socio-economic development." Journal of Procurement Management 12 (6):652-668.

[5] Bals, Lydia, and Virpi Turkulainen. 2017a. "Achieving efficiency and effectiveness in Purchasing and Supply Management: Organization design and outsourcing." Journal of Purchasing Supply Management 23 (4):256-267.

[6] Bals, Lydia, and Virpi Turkulainen. 2017b. "Achieving efficiency and effectiveness in Purchasing and Supply Management: Organization design and outsourcing." J Journal of Purchasing Supply Management 23 (4):256-267.

[7] Bhattacherjee, Anol. 2012. "Social science research: Principles, methods, and practices."

[8] Bonifield, Carolyn M, and Catherine A Cole. 2020. "COMPREHENSION OF AND VULNERABILITY TO PERSUASIVE MARKETING COMMUNICATIONS AMONG OLDER CONSUMERS." The Aging Consumer: Perspectives from Psychology Marketing:182.

[9] Edler, Jakob, and Jillian Yeow. 2016. "Connecting demand and supply: The role of intermediation in public procurement of innovation." Research Policy 45 (2):414-426.
[10] Harrison, Helena, Melanie Birks, Richard Franklin, and Jane Mills. 2017. "Case study research: Foundations and methodological orientations." Forum Qualitative Sozialforschung/Forum: Qualitative Social Research.

[11] Heath, Joseph, and Wayne Norman. 2004. "Stakeholder theory, corporate governance and public management: what can the history of state-run enterprises teach us in the post-Enron era?" Journal of business ethics 53 (3):247-265.

[12] Knack, Stephen, Nataliya Biletska, and Kanishka Kacker. 2019. "Deterring kickbacks and encouraging entry in public procurement markets: Evidence from firm surveys in 90 developing countries." The World Bank Economic Review 33 (2):287-309.

[13] Kwasi, Stephen Nkesah. 2020. "Suppliers Approach to Sustainable Procurement: A Case Study of Ghana Cocoa Board." Høgskolen i Molde-Vitenskapelig høgskole i logistikk.

[14] Luu, Ngoc, Jack Cadeaux, and Liem Viet Ngo. 2018. "Governance mechanisms and total relationship value: the interaction effect of information sharing." Journal of Business Industrial Marketing.

[15] Lyrio, Maurício Vasconcellos Leão, Rogério João Lunkes, and Emma Teresa Castelló Taliani. 2018. "Thirty years of studies on transparency, accountability, and corruption in the public sector: The state of the art and opportunities for future research." Public Integrity 20 (5):512-533.

[16] Nadi, Mohammad Ali. 2018. "The structural model of relationship between organizational trust and organizational commitmen with knowledge sharing behavior: The mediation of organizational culture and organizational Health Teachers." Journal of New Approaches in Educational Administration 9 (35):291-310.

[17] Sarfo, Patrick Adu, and Richard Baah-Mintah. 2013. "Assessing the effect of the procurement act (663) on the public financial management in Ashanti region." American Journal of Rural Development 1 (4):91-98.

[18] Sönnichsen, Sönnich Dahl, and Jesper Clement. 2020. "Review of green and sustainable public procurement: Towards circular public procurement." Journal of cleaner production 245:118901.

[19] Stebbins, Robert A. 2001. Exploratory research in the social sciences. Vol. 48: Sage.

[20] Suryanto, Tulus, Muhammad Haseeb, and Nira Hariyatie Hartani. 2018. "The correlates of developing green supply chain management practices: Firms level analysis in Malaysia." International Journal of Supply Chain Management 7 (5):316.

[21] TIREFA, WOSSENE MESELE. 2019. "Baynesagn Asfaw (Ph. D.)." Ethiopian Civil Service University.

[22] Titl, Vitezslav, and Benny Geys. 2019. "Political donations and the allocation of public procurement contracts." European Economic Review 111:443-458.

[23] Tufford, Lea, and Peter Newman. 2012. "Bracketing in qualitative research." Qualitative social work 11 (1):80-96.

[24] Wilmshurst, Trevor D, and Geoffrey R Frost. 2000. "Corporate environmental reporting." Accounting, Auditing Accountability Journal. 